\title{
Length of Diagnostic Delay in Patients with Non-small-cell Lung Cancer
}

\author{
Solangel Valdés, MD, Eberto García MD, MPH, Hayvin Pérez, MD, MPH, Marisela Hernández, MD
}

\begin{abstract}
Introduction Despite advances in diagnostic techniques and treatment, lung cancer is the leading cause of cancer death worldwide and in Cuba. Prompt initiation of cancer therapy depends on rapid diagnostic confirmation; however, most patients are diagnosed at an advanced stage. In the Cuban health system, primary, secondary and tertiary levels of care are interrelated; patients may seek care at any level or may be referred from one to another. Lung cancer diagnoses are confirmed at the tertiary level.
\end{abstract}

Objective Determine the length of diagnostic delay in patients diagnosed with non-small-cell lung cancer (NSCLC) at a tertiary care facility in Havana, Cuba, as well as mean diagnostic delay attributable to the patient and to the health system by level of care.

Methods A descriptive observational study of 96 patients with a cytologically and/or histologically confirmed diagnosis of non-small-cell lung cancer was conducted in 2005-2007. Patients initially sought care for disease symptoms at primary, secondary or tertiary levels in the Cuban public health system, but diagnosis of all patients was confirmed at a specialized tertiary care facility. Total diagnostic delay was calculated as the time elapsed from onset of symptoms to confirma- tion of NSCLC diagnosis. Variables also included diagnostic delay attributable to the patient and diagnostic delay attributable to the health system by level of care. Data were arranged in tables and analyzed by absolute value, percentage, mean, and standard deviation.

Results Of the 96 patients studied, $69 \%$ were male, and $54 \%$ were aged 50-69 years. Fifty-five percent of patients sought medical care within 15 days of onset of symptoms, $21 \%$ within $16-30$ days, and $3 \%$ waited $>90$ days. Mean diagnostic delay attributable to the patient was $18.19 \pm 3.45$ days while mean diagnostic delay attributable to the health system was $61.63 \pm 18.50$ days, and overall diagnostic delay was $73.13 \pm 17.53$ days. For the $71 \%$ of patients seen in primary care, mean diagnostic delay was $29.51 \pm 4.53$ days; for the $45 \%$ seen exclusively or additionally at the secondary level, mean diagnostic delay was $24.45 \pm 7.31$ days. Upon admission at the tertiary care level, mean diagnostic confirmation delay was $18.23 \pm 3.68$ days.

Conclusions Diagnostic delay of lung cancer patients in this study was prolonged. Appropriate strategies are needed for reducing this delay.

Keywords: Lung cancer, non-small-cell lung carcinoma, diagnosis, delivery of health care

\section{INTRODUCTION}

Lung cancer is the leading cause of cancer death worldwide with non-small-cell lung cancer (NSCLC) making up about $85 \%$ of all lung cancers worldwide.[1] It is also the most common cancer and leading cause of cancer death in Cuba.[2] In 2007, 4819 people died from lung cancer in Cuba, a mortality rate of 42.9 per 100,000 population.[3]

In contrast to other solid tumors, such as those of the breast and prostate, the 5-year survival rate after diagnosis of lung cancer has remained $<10 \%$ internationally for several decades.[4,5] Although many factors are involved, one of the most important is diagnosis at late stages of the disease, which affects the majority of patients.[6,7]

Early detection involves a set of actions aimed at discovering a disease before the patient presents signs or symptoms. In the specific case of lung cancer, substantial resources have gone into screening, targeted primarily at the population at highest risk (smokers). Nevertheless, research and programs designed and carried out in many countries have not succeeded in generating significant early detection.[8-10] Furthermore, once the symptomatic patient enters the health system, diagnosis must be made as quickly as possible to enable prompt initiation of cancer therapy.[11]

In Cuba's national public health system, primary, secondary and tertiary care operate as three interrelated levels. Primary care, including neighborhood family doctors and community-based polyclinics, is usually the level of first contact. The secondary level is comprised of referral facilities, such as general hospitals, and the tertiary level consists of specialized institutes and hospitals providing services with the most advanced technology. [12] Patients may seek care at any one of these levels on their own initiative, or they may be referred by physicians from one level to another. Thus, a patient seen initially at the primary care level may ultimately be diagnosed and treated at the tertiary level.[13]

Primary health care for lung cancer covers population-wide prevention activities as well as periodic check-ups of individuals with risk factors, including active or passive smokers aged $>40$ years, persons with occupational exposure to inhaled carcinogens, and patients with chronic obstructive pulmonary disease (COPD) or pulmonary fibrosis. These check-ups are aimed at detecting disease symptoms and include radiological exams, if necessary. Lung cancer symptoms include cough, coughing up phlegm, hemoptysis, chest pain, and shortness of breath, which may be attributed to a pulmonary tumor, metastasis, or paraneoplastic syndromes.

When results of clinical or radiological exams indicate possible lung cancer (presumptive diagnosis), the primary care physician refers the patient to the multidisciplinary cancer care team at the nearest reference hospital, or to a specialized oncology or pulmonology center, where resources are available for confirming the diagnosis, disease staging, and treatment.[14]

The objective of the present study was to identify the length of diagnostic delay in a group of patients diagnosed with non-small- 
cell lung cancer by determining the time elapsed from onset of symptoms to confirmation of diagnosis.

\section{METHODS}

A descriptive observational study was conducted of 96 patients with confirmed NSCLC who were discharged from the Pedro Rabiña Pulmonology Service of the Benéfico Jurídico Pulmonary Teaching Hospital in Havana during the 3-year period from 2005 to 2007. Before admission to this tertiary care facility, patients may have been examined and treated for symptoms at the primary or secondary care levels, or both, or they may have gone directly to the specialized tertiary-level service. Regardless of their entry point in the health system, diagnosis of NSCLC was cytologically and/or histologically confirmed in all patients at the tertiary level, where they also received treatment and follow-up.

All participants, including patients and family members, provided informed consent, and the study was approved by the hospital's Medical Ethics Committee.

Data was obtained through interviews with patients and their relatives, and from medical records, clinical history summaries, and case referrals. All interviews were conducted and medical records reviewed directly by the authors, who were also the patients' attending physicians. The information was collected on individual forms and then entered into a database created using Microsoft Office Excel 2007.

Variables examined were age (in years at time of admission), sex, and length of diagnostic delay, defined as follows:

- Total diagnostic delay: time elapsed from onset of symptoms until cytological and/or histological confirmation of NSCLC diagnosis, expressed in days. Total delay was then subdivided by attribution to the patient or the health system:

- Patient-attributed diagnostic delay: time elapsed from onset of symptoms until first medical consultation for disease symptoms at any level of care, expressed in days.

- Health system-attributed diagnostic delay: time elapsed from patient's first medical consultation for disease symptoms until confirmation of diagnosis, expressed in days and also subdivided by level of care:

- Diagnostic delay in primary care: time elapsed from first primary care consultation for symptoms until referral (with or without presumptive diagnosis) to secondary or tertiary level of care for diagnosis.

- Diagnostic delay in secondary care: time elapsed from initiation of patient care at this level until referral or transfer (with or without presumptive diagnosis) to tertiary level (specialized hospital) without diagnostic confirmation.

- Diagnostic delay in tertiary care: time elapsed from patient admission to the specialized hospital until cytological and/or histological confirmation of NSCLC diagnosis.

Data analysis Absolute value, percentage, range, mean, and standard deviation (SD) were calculated and presented in tables. Statistical analysis was made using EPIDAT 3.1 software.

\section{RESULTS}

Over half the sample studied (69\%) were men, and $54 \%$ were aged $50-69$ years (age range $32-88$ years) (Table 1 ).
Table 1: Patients with Confirmed NSCLC Diagnosis, Pedro Rabiña Pulmonology Service, Havana, 2005-2007, by Sex and Age

\begin{tabular}{|c|c|c|}
\hline \multicolumn{3}{|c|}{ Sex } \\
\hline & No. & $\%$ \\
\hline Male & 67 & 69 \\
\hline Female & 29 & 31 \\
\hline \multicolumn{3}{|c|}{ Age Group (Years) } \\
\hline $30-49$ & 19 & 20 \\
\hline $50-69$ & 52 & 54 \\
\hline $70-89$ & 25 & 26 \\
\hline
\end{tabular}

NSCLC: Non-small-cell lung cancer

Mean overall diagnostic delay was 73.13 (SD \pm 7.53 ) days. Mean health system-attributed diagnostic delay (61.63 days, SD $\pm 18.50)$ was more than three times the mean patient-attributed diagnostic delay (18.19 days, SD \pm 3.45 ) (Table 2 ).

Over half the patients (55\%) sought medical care within the first 2 weeks following onset of symptoms with a mean delay in seeking care of about one week ( 7.96 days, SD \pm 4.64$)$. As the mean length of patient-attributed delay increased, the number of patients seeking initial medical care for disease symptoms decreased; only 3 patients waited more than 90 days following onset of symptoms before seeking medical care (Table 3).

Table 2: Length of Diagnostic Delay in NSCLC Patients

\begin{tabular}{|l|r|r|}
\hline Diagnostic Delay & $\begin{array}{r}\text { Mean Length of Delay } \\
\text { (Days) }\end{array}$ & \multicolumn{1}{c|}{ SD } \\
\hline Patient-attributed & 18.19 & \pm 3.45 \\
\hline Health system-attributed & 61.63 & \pm 18.50 \\
\hline Overall & 73.13 & \pm 7.53 \\
\hline NSCLC: Non-small-cell lung cancer & & \\
\hline
\end{tabular}

SD: Standard deviation

Table 3: Length of Patient-Attributed Diagnostic Delay

\begin{tabular}{|l|r|r|r|r|}
\hline \multirow{2}{*}{ Diagnostic Delay (Days) } & \multicolumn{2}{|c|}{ Patients } & \multirow{2}{*}{ Mean } & \multicolumn{1}{l|}{ SD } \\
\cline { 2 - 5 } & No. & $\%$ & & \\
\hline$\leq 15$ & 53 & 55 & 7.96 & \pm 4.64 \\
\hline $16-30$ & 20 & 21 & 26.55 & \pm 5.82 \\
\hline $31-60$ & 13 & 14 & 55.38 & \pm 9.45 \\
\hline $61-90$ & 7 & 7 & 80.42 & \pm 11.46 \\
\hline$>90$ & 3 & 3 & 151.33 & \pm 13.21 \\
\hline
\end{tabular}

SD: Standard deviation

Most patients (68/96) were initially seen in primary care, and diagnosis was confirmed for all patients at the tertiary care level. Mean length of diagnostic delay from initial consultation in primary care to confirmed NSCLC diagnosis was about one month (29.51 days, SD \pm 4.53 ). Mean length of diagnostic delay was slightly less from secondary care to confirmed diagnosis (24.45 days, SD \pm 7.31 ), and was shortest from patient admission to tertiary care to confirmed diagnosis (18.23 days, SD \pm 3.68 ) (Table 4).

Table 4: Length of Health System-Attributed Diagnostic Delay by Level of Care

\begin{tabular}{|l|r|r|l|}
\hline Level of Health Care & $\begin{array}{c}\text { No. of } \\
\text { Patients }\end{array}$ & $\begin{array}{c}\text { Mean Length of } \\
\text { Delay (Days) }\end{array}$ & \multicolumn{1}{l|}{ SD } \\
\hline Primary & 68 & 29.51 & \pm 4.53 \\
Secondary & 43 & 24.45 & \pm 7.31 \\
\hline Tertiary & 96 & 18.23 & \pm 3.68 \\
\hline
\end{tabular}

SD: Standard deviation

\section{DISCUSSION}

In most lung cancer patients, diagnosis at an advanced stage results in a poor prognosis and short survival time. Delayed diagnosis has many, complex causes and depends as much on the biological behavior and clinical manifestations of tumors as on 
the individual characteristics of patients, their families and their particular socioeconomic situation.[15-18]

People with lung cancer may not seek medical care until several years after onset of the disease. They may be asymptomatic at first; later, they may ascribe respiratory symptoms (cough, coughing up phlegm, shortness of breath, chest pain, etc.) to smoking, a pre-existing bronchopulmonary condition, acute respiratory disease, or even to lack of rest or aging. $[17,18]$ Other factors associated with patient delay in seeking medical care include access to services, personal and family opinion of medical services, health education, educational level, and family support.[5,19]

Length of patient-attributed diagnostic delay in lung cancer patients has been found to vary in different countries, ranging from 7 days in one study in Italy to $>90$ days in another carried out in the United States.[20] Variations have also been reported in the same country; for example, in Spain, Ruiz et al.[21] found a patient-attributed delay of 26 days compared to 69 days in a study by Navarro et al.[22]

By comparison, we consider the patient-attributed delay found in this study acceptable, particularly the high percentage of patients $(55 \%)$ seeking care within 2 weeks of symptom onset and the overall mean patient-attributed delay of 18.19 days. These results are consistent with the Cuban population's high level of education with repercussion in levels of health education, confidence in medical services, and above all, ease of access to health care, independent of geographic and sociocultural factors.[13]

This study also confirms that most people with lung cancer symptoms initially seek care at the primary level, as observed by other authors,[21,23] highlighting the importance of making presumptive diagnosis based on clinical and/or radiological exams at this level and referring the patient as quickly as possible to higher levels of care for confirmation. Referral to secondary or tertiary care for diagnostic confirmation is frequently delayed, however, because primary care physicians worldwide often fail to consider a lung cancer diagnosis even in patients with risk factors, persistent respiratory symptoms, and simple chest $\mathrm{x}$-rays with lesions that do not improve with appropriate antibiotic treatment. These physicians tend to insist, instead, on antibiotic treatment, creating a false sense of security in patients and their families and delaying referral. In developing future strategies, it is therefore important to recognize that initial primary care conduct and its relation with other levels of care can significantly influence the length of diagnostic delay in lung cancer patients.[24,25]

In the present study, $45 \%$ of patients received care at the secondary level, where the delay until referral to tertiary care for diagnostic confirmation was almost as long as the delay in referral from primary care. One reason for this may be that a particular diagnostic tool is unavailable in a certain institution. Another may be the frequent decision to wait and observe the evolution of the patient after insisting on treatment with antibiotics, demonstrating flaws in the clinical method at this level of care contributing to longer diagnostic delays.[26,27]

In a study in the city of Camagüey (Cuba), Monteagudo et al. found that almost $50 \%$ of lung cancer patients were diagnosed
30 days after admission to secondary care.[28] These authors managed to reduce the length of diagnostic delay by $40 \%$ in a secondary care hospital through implementation of an integrated algorithm, resulting in earlier diagnosis with the same technological and human resources, through application of the clinical method in conjunction with reorganization and correct use of such resources.

Given that most patients are admitted to tertiary care with a wellfounded suspicion of diagnosis, and considering the availability of specialized, highly-skilled services in these facilities, mean time to confirmed NSCLC diagnosis has been estimated at 7-10 days in various international studies.[24,29] However, this study found that mean length of diagnostic delay at the tertiary level was somewhat longer, although very similar to that reported by other authors in studies done at this level of care in Spain.[22,29,30] In our institution, this situation may be mainly due to delays in obtaining results of exams not performed on site, such as computerized axial tomography, or to patients' postponement or refusal of invasive procedures, such as bronchoscopy and transparietal fine-needle aspiration biopsy.

Despite technological advances and screening programs aimed at early lung cancer detection, research in developed and developing countries continues to show prolonged diagnostic delay of this disease.[31,32] Mean overall length of diagnostic delay in lung cancer patients has been estimated at 60-90 days globally,[33] and the findings of this study are within this range.

A main limitation of this study was failure to include the disease stage of each patient at time of diagnostic confirmation. At early stages, however, symptoms are rare and may be discounted by both the patient and the treating physician, thereby prolonging both time to recognition of symptoms by the patient and recognition of cancer warning signs by the physician, all of which impact the length of diagnostic delay.

Although mean length of patient-attributed diagnostic delay was only about 7 days in over half the patients in this study, we believe health activities aimed especially at individuals with lung cancer risk factors should be broadened at all levels of care. Smokers should receive not only education and support to stop smoking but also to help them recognize changes in their state of health that may be warning signs of lung cancer. Others at high risk for developing lung cancer, such as individuals with occupational exposure to inhaled carcinogens and patients with COPD or pulmonary fibrosis, should be similarly targeted.

We consider the length of health system-attributed diagnostic delay found in this study prolonged and in need of improvement. To this end, we recommend further research on the causes influencing such delays at all levels of health care and-once these are identified-implementing strategies aimed at shortening the time between initial consultation for disease symptoms and diagnostic confirmation of NSCLC.

Results of this and similar studies conducted at different levels of care may also be used to develop diagnostic algorithms and clinical best practices guidelines. Such tools for reducing diagnostic delay could then enable rapid initiation of stage-specific 
therapy, taking into account the technological and human resources available at each level of care and interrelationships among levels of care.

\section{CONCLUSIONS}

This study found that diagnostic delay of non-small-cell lung cancer in the Cuban health care system was prolonged and was primarily attributable to the health care system rather than the patient. Strategies aimed at reducing this delay are therefore needed, particularly organizational and service delivery measures. Given the interrelationship among levels of care and the constant introduction of advanced medical technologies at all levels of health care, implementation and eventual success of such strategies may be regarded as achievable goals. -1 -

\section{REFERENCES}

1. Herbst R, Heymach J, Lippman S. Lung Cancer. N Engl J Med. 2008;359:1367-80

2. Galán $Y$, Fernández L, Torres P, García M. Trends in Cuba's Cancer Incidence (1990 to 2003) and Mortality (1990 to 2007). MEDICC Review. 2009;11(3):19-26.

3. Ministry of Public Health (CU), National Statistics Division. Anuario Estadístico de Salud 2007. Havana; 2008.

4. Moody A, Muers M, Forman D. Delays in managing lung cancer. Thorax. 2004 Jan;59(1):1-3.

5. Birring SS, Peake MD. Symptoms and the early diagnosis of lung cancer. Thorax. 2005 Apr:60(4):268-9.

6. Duménigo O, De Armas B, Gil A, Gordis MV. Nódulo pulmonar solitario: Qué hacer. Rev Cubana Cir [serial on the Internet]. 2007 Jun [cited 2008 Jan 26];46(2). Available from: http:// www.imbiomed.com.mx/1/1/articulos.php?id_ revista $=57 \&$ id ejemplar $=4869$

7. Sánchez I, Izquierdo JL, Almonacid C. Situación epidemiológica y pronóstica del cáncer de pulmón en nuestro medio. Arch Bronconeumol. 2006;42:594-9.

8. Cañizares MA, Rivo JE, Blanco M, Toscazo A, García EM, Purriños MJ. Influencia de la demora quirúrgica en la supervivencia de los pacientes intervenidos por carcinoma broncogénico. Arch Bronconeumol. 2007;43(3):165-70.

9. Ministry of Public Health (CU). Programa nacional de reducción de la mortalidad por cáncer. Havana; 1998.

10. National Oncology and Radiobiology Institute (CU). Cáncer de pulmón. Guía de diagnóstico y tratamiento. Havana; 2001.

11. Myrdal G, Lambe M, Hillerdal G, Lamberg K Agustsson T, Ståhle E. Effect of delays on prognosis in patients with non-small-cell lung cancer. Thorax. 2004 Jan;59(1):45-9.

12. Van der Stuyft $P$, De Vos P. La relación entre los niveles de atención constituye un determinante clave de la salud. Rev Cubana Salud Pública [serial on the Internet]. 2008 Dec [cited 2009 May 22];34(4). Available from: http://scielo.sld. $\mathrm{cu} / \mathrm{scielo}$.php? script=sci_arttext\&pid=S0864$34662008000400014 \&$ lng=es\&nrm=iso.

13. Rojas F. La Salud Pública Revolucionaria Cubana en su aniversario 50. Rev Cubana Salud Pública [serial on the Internet]. 2009 Mar [cited 2009 May 22];35(1). Available from: http://scielo. sld.cu/scielo.php?script=sci_arttext\&pid=S086434662009000100003\&lng=es\&nrm=iso.

14. National Cancer Control Unit (CU). Programa integral para el control del cáncer en Cuba. Pautas para la gestión. Vol. 1. Havana; 2009.

15. Torres AJ. Demora en el tratamiento quirúrgico del cáncer de pulmón. An Med Interna (Madrid). 2005 Aug;22(8):359-60.

16. Corner J, Hopkinson J, Fitzsimmons D. Is late diagnosis of lung cancer inevitable? Interview study of patients' recollections of symptoms before diagnosis. Thorax. 2005 Apr;60(4):314-9.

17. Geddes DM. The natural history of lung cancer: a review based on tumour growth. $\mathrm{Br} J$ Dis Chest. 1979;73(1):1-17.
18. Booton $\mathrm{R}$, Jones $\mathrm{M}$, Thatcher $\mathrm{N}$. Lung cancer 7 : management of lung cancer in elderly patients. Thorax. 2003 Aug;58(8):711-20.

19. Porter JC, Spiro SG. Detection of early lung cancer. Thorax. 2000 Aug;55 Suppl 1:S56-62.

20. Jensen AR, Mainz J, Overgaard J. Delay on diagnosis and treatment of lung cancer. Lung cancer. 2002;37:227-8.

21. Ruiz Torrejón A, Ramos Montserrat MJ, Llobera Cánaves J. El médico de atención primaria y el diagnóstico de los pacientes con cáncer. Atención primaria. 2006;37(1):16-21.

22. Navarro J, Rodríguez $R$, Juanes A, Díaz F, Cabrera P. Tiempos de demora en el carcinoma broncogénico. Arch Bronconeumol. 2006;42(Espec Congr):85.

23. Cordovilla R, Serrano AR, González JM, Fernández JL, Moreno de Vega B, Ramos $\mathrm{J}$, et al. Demoras diagnósticas en el cáncer de pulmón. Arch Bronconeumol. 2003 Oct;39(10):437-41

24. Pajares V, Torrego A, Puzo MC, Plaza V, Bolivara I, Sanchos J. Resultados de la instrumentación de un programa de diagnóstico y tratamiento rápido del cáncer de pulmón. Arch Bronconeumol. 2007;43(Espec Congr):84

25. Hamilton W, Sharp D. Diagnosis of lung cancer in primary care: a structure review. Fam Pract. 2004 Oct 1;21(6):605-11.

26. Monteagudo A, Romero RE, Salazar CE. Cáncer de pulmón, propuesta ética para agilizar su diagnóstico. Rev Hum Med [serial on the Internet]. 2007 Aug [cited 2008 Jan 22];7(2). Available from: http://scielo.sld.cu/scielo.php?script=sci arttext\&pid=S1727-81202007000200004\&lng= es\&nrm=iso\&tlng=es

27. Hirsh K, Gunnar H, Brandén E. Patient's and doctor's delays in the diagnosis of chest tumors. Lung cancer. 2002 Jan;35(1):53-7.

28. Monteagudo A, MoraA, García O. Las relaciones ciencia-tecnología-sociedad en el diagnóstico temprano del cáncer del pulmón. Rev Hum Med [serial on the Internet]. 2004 Aug [cited 2008 Jan 22];4(2). Available from: http://scielo.sld. $\mathrm{cu} /$ scielo.php? script $=$ sci_issuetoc $\&$ pid $=1727$ $812020040002 \& \operatorname{lng}=e s \& n r m=$ iso

29. Gómez F, Casitas R, García M. Implantación de una consulta protocolizada de diagnóstico rápido de cáncer de pulmón. Arch Bronconeumol. 2006;42(Espec Congr):80.

30. Valdivia M, Martínez J, Guillamón M, Sánchez J, de la Torre J, Santacruz A. Tiempo empleado en el diagnóstico y estadiaje de tumores torácicos. Arch Bronconeumol. 2007;43(Espec Congr):86.

31. Dische S, Gidson D, Parmar D, Saunders MI. Timer course from first symptom to treatment in patient with non-small-cell lung cancer referred for radiotherapy, a report by CHART steering committee. Thorax. 1996 Dec:51(12):1262-5.

32. González JM, de Castro F, Barrueco M, Cordobilla R, Fernández J, Gómez FP. Demoras diagnósticas en el cáncer de pulmón. Arch Bronconeumol. 2003;39:437-41.

33. Carbone P. Lung Cancer: Early Events, Early Interventions: Conference Summary for the 46th Annual Thomas L. Petty Aspen Lung Conference. Chest. 2004 May;125(5):167-72.

\section{THE AUTHORS}

Solangel Valdés Díaz, pulmonologist. Associate professor, Hospital Neumológico Benéfico Jurídico, Havana, Cuba.

Eberto García Silvera (Corresponding Author: ebertog@infomed.sld.cu), pulmonologist, specialist in family medicine and MPH in infectious diseases. Instructor, Hospital Neumológico Benéfico Jurídico, Havana, Cuba.

Hayvin Pérez Cruz, pulmonologist, specialist in family medicine and MPH in healthy aging and longevity. Instructor, Hospital Neumológico Benéfico Jurídico, Havana, Cuba.

Marisela Hernández Hernández, pulmonologist, Hospital Neumológico Benéfico Jurídico, Havana, Cuba.

Submitted: December 10, 2008 Approved for publication: November 6, 2009 